\title{
Multiple Parameter Optimization of Hydration Characteristics and Proximate Compositions of Rice-Soybean Extruded Foods
}

\author{
Danbaba Nahemiah ${ }^{1,2 *}$, Iro Nkama3 ${ }^{3}$ Mamudu Halidu Bada², David Iordehiin Gbenyi", \\ Paul Yahaya Idakwo ${ }^{2}$, Sali Atanga Ndindeng5, Jean Moreira ${ }^{5}$
}

${ }^{1}$ Food Technology and Value Addition Research Program, National Cereals Research Institute (NCRI), Badeggi, Nigeria

${ }^{2}$ Department of Food Science and Technology, University of Maiduguri, Maiduguri, Nigeria

${ }^{3}$ Department of Food Science and Technology, University of Nigeria, Nsukka, Nigeria

${ }^{4}$ Department of Food Science and Technology, Federal Polytechnic, Mubi, Nigeria

${ }^{5}$ Africa Rice Center (AfricaRice), Cotonou, Benin

Email: *dnahemiah@gmail.com

How to cite this paper: Nahemiah, D., Nkama, I., Bada, M.H., Gbenyi, D.I., Idakwo, P.Y., Ndindeng, S.A. and Moreira, J. (2017) Multiple Parameter Optimization of Hydration Characteristics and Proximate Compositions of Rice-Soybean Extruded Foods. Open Access Library Journal, 4: e2930.

https://doi.org/10.4236/oalib.1102930

Received: December 29, 2016

Accepted: February 3, 2017

Published: February 6, 2017

Copyright $\odot 2017$ by authors and Open Access Library Inc.

This work is licensed under the Creative Commons Attribution International License (CC BY 4.0).

http://creativecommons.org/licenses/by/4.0/ (c) (i) Open Access

\begin{abstract}
Multi-parameter extrusion cooking conditions for the extrusion of composite flours of rice and soybean were modeled using response surface methodology (RSM). A five-level-three-factors central composite rotatable design (CCRD) was employed to optimize three process variables including barrel temperature $(\mathrm{BRT})\left(X_{1}\right)$, feed moisture $(\mathrm{FMC})\left(X_{2}\right)$ and feed soybean composition (FSC) $\left(X_{3}\right)$ for the achievement of satisfactory hydration characteristics and proximate composition. The fitted polynomial models indicated significant coefficients, satisfactory coefficients of determination $\left(R^{2}\right.$ and $\left.R_{\text {adjusted }}^{2}\right)$ and non-significant lack-of-fit test. Optimum $X_{1}, X_{2}$ and $X_{3}$ were $120^{\circ} \mathrm{C}, 20 \%$, and $23 \%$ for rice-soybean based extrudates. At these optimum combinations, optimum responses were $97.10 \%$ for dispersibility, 6.11 water absorption index and 8.42 water solubility index, while proximate composition of $1.02 \%$ moisture content, $3.62 \%$ lipid, $26.26 \%$ protein, $0.48 \%$ ash content, $2.14 \%$ fibre, $70.13 \%$ and $412.14 \mathrm{kcal} / 100 \mathrm{~g}$ of energy were obtained. Under the optimized conditions, the responses are well matched with the predicted values and therefore the models could be used to predict the extrusion system in its natural state.
\end{abstract}

\section{Subject Areas \\ Analytical Chemistry, Food Science \& Technology}

\section{Keywords}

Optimization, Extrusion, Rice, Soybean, Hydration Properties, Proximate 


\section{Introduction}

Rice (Oryza sativa L.) is one of the important crops in the world in terms of the amounts produced by developing world $\left(480 \times 10^{6}\right.$ tons of rough rice in 2012) and the number of people (3.5 billion) that depend on it as their staple food and sustenance [1]. The global per capita consumption of milled rice was $54.5 \mathrm{~kg}$ per person per year in 2014, this includes $77 \mathrm{~kg}$ in Asia, $31 \mathrm{~kg}$ in South America, $21 \mathrm{~kg}$ in Africa, $14 \mathrm{~kg}$ in Oceania, and $<10 \mathrm{~kg}$ in Europe and North America [1]. In Nigeria, per capita consumption was $32 \mathrm{~kg}$ per person per year with urban consumption exceeding $47 \mathrm{~kg} /$ person/year [2] which is significantly higher than the regional average. More than 3.5 billion people depended on rice for more than $20 \%$ of their daily calorie requirement in 2009 and more than $50 \%$ of energy supply for more than 520 million people in Asia and sub-Saharan Africa (SSA) provides, most of whom are poor to very poor [1] [2].

But on the overall nutritional assessment, rice has low protein contents (7\% $9 \%)$ with slightly high lysine ( $4 \%-5 \%)$ content when compared with some common cereals such as sorghum, millet, maize and wheat, which corresponding to an amino acid score of $67 \%$ in milled rice [1]. Rice based products can easily therefore be improved by complementing with food materials richer in lysine [3]. Food legumes have been proven to be comparatively richer in lysine and therefore combination of cereal and legume proteins provides an ideal source of dietary protein for humans [3] [4] especially in less developed countries where animal protein is beyond the reach of average populations.

The utilization of locally grown crops such as cowpea, soybean, groundnuts, sesame and Bambara groundnut for the production of high protein, energy and affordable recipes has been proposed as a suitable channel for addressing protein-energy malnutrition (PEM) in industrially less developed nations. Especially, when these products are processed using technology that results in shelf stable, convenient and consumer acceptable products, it will contribute significantly to the overall food and nutrition security of the populace [3] [4] [5]. Legumes are second only to cereals in their importance to human nutrition [6]. Legumes when processed into flour can be used in the preparation of composite flour bread, doughnuts, tortillas, chips, spreads and extruded snacks and porridges or used in liquid form to produce milk analogues and infant formulations [7] [8]. Recent studies indicated that flavones extracted from soybean and other legumes had been suggested to both reduce the risks of cancer and also lower cholesterol level in human [9] [10]. Soybean phytoestrogens have also been suggested as possible alternative to hormone replacer in postmenopausal therapy [8]. According to Iyer et al. [11], the necessity for laborious preparation before consumption, long cooking time and the high level of anti-nutritional 
factors which causes gastro-intestinal disorder after consumption are major contributing factors limiting the utilization of legumes as human foods worldwide. But food processing methods such as soaking, germination, cooking, blanching, roasting, frying, canning and more recently extrusion cooking has been used to minimize these factors in legumes and enhance its utilization [8] [11].

Extrusion cooking (EC) is a high temperature short time (HTST) food processing technique, in which mechanical energy is combined with heat energy to cook starch, plasticizing and reorganizing food materials to create at the die new shaped and textured products, and also has the ability to inactivate enzymes, destroy anti-nutritional factors and reduce microbial activity [12] [13] [14] [15]. EC has been used in the cereal industry for several years to produce diverse foods such as breakfast cereals, snack foods, baby foods, pasta products, extruded bread, modified starches, beverages powders, meat and cheese analogues, textured vegetable protein, and blended foods such as corn starch and ground meats [16] [17]. During EC, due to the varying extrusion conditions, such as extruder parameters, raw materials composition, moisture level and $\mathrm{pH}$, chemical and structural changes occurs in the raw materials, these changes includes starch gelatinization [18], protein denaturation [4], pigment and vitamin degradation, and loss of volatile compounds. These changes resulted in new food product with new functional, nutritional and sensory qualities [19]. Several researchers [4] [5] [14] [16] [17] [18] [20] [21] [22] has developed food products using this technology and reported need for a systematic evaluation of appropriate extrusion variable settings to achieve the optimum quality of finished product.

But the method for the optimization of food production system by varying a single parameter at a time while holding the other parameters at a specified level have been found to be labor intensive, time consuming and economically expensive especially where the system is multiple variables dependent. Multivariate approach using response surface methodology (RSM) and designed experiment provides a more efficient, cost and energy effective alternative by examining simultaneously and systematically more than one variable at a time and their interaction [22]. This approach allows researcher to establish mathematical relationships between input variables and product properties [23] that could be used to predict the process parameters in their natural state.

In view of the industrial potentials of broken rice flour and common legumes in the production of high protein and energy foods that may be used for sustainable protein-energy-malnutrition (PEM) mitigation in developing countries, and the cost effectiveness of EC technology in the development of novel food products, the present study was designed and conducted to optimize extrusion conditions for the production of extruded foods using broken rice fractions blended with soybean. RSM and central composite rotatable design (CCRD) were used for identifying critical process variables and optimizing them for optimum hydration and proximate composition. 


\section{Materials and Methods}

\subsection{Materials Sampling and Formulation}

Broken rice (FARO 52) fractions were obtained from the Rice Processing Unit and Soybean (TGX-1448-2E) was purchased from the Soybean Research Program of the National Cereals Research Institute (NCRI), Badeggi, Niger State, Nigeria. All the materials were manually cleaned and packaged in sealed polyethylene bags at room temperature $\left(30^{\circ} \mathrm{C} \pm 2^{\circ} \mathrm{C}\right)$ until required. The broken rice fractions were washed in clean water and dried to about $12 \%$ moisture content at room temperature $\left(32^{\circ} \mathrm{C} \pm 2^{\circ} \mathrm{C}\right)$. The dried grains were then grinded in an attrition mill (locally fabricated) before sieving with $150 \mu \mathrm{m}$ laboratory sieve (Brabender OHG Duisburg type). While, twenty (20 kg) kilograms of soybean was separately steeped in tap water at room temperature in a 20 liters plastic bowls. After $24 \mathrm{hrs}$, the soybean were dehulled using traditional wooden pestle and mortar and after several washing, the dehulled grain were dried to about $14 \%$ moisture content in an oven before manually winnowed to have clean dehulled seeds. The dried seeds were then milled into flour and stored in sealed polyethylene bags until required.

Twenty (20) different composite flour blends were formulated based on preliminary trials. The blends were conditioned to appropriate moisture content [24] by spraying with calculated amount of water and mixing continuously at medium speed in a blender. The samples were put in closed plastic buckets and stored overnight. The feed materials were then allowed to stand for $3 \mathrm{hrs}$ to equilibrate at room temperature prior to extrusion exercise.

\subsection{Extrusion Cooking Exercise}

The different rice-soybean formulations were subjected to extrusion cooking using a twin-screw extruder (SLG 65, Jinan SaibainoTechn. Dev. Co. Ltd, China). Feeds were manually introduced at a speed of $30 \mathrm{rpm}$ which insure that the flight of the screw was filled and avoiding accumulation of fed in the hopper. Desired barrel temperature was maintained by in-build thermostat and a temperature control unit. Experimental samples were collected as steady state was achieved [25] [26]. Since the operation was replicated three times, averages of 20 runs per day were possible (three days) which resulted in 60 individual extrusion runs. Extruded samples were collected and subjected to hydration characteristics and proximate composition analysis.

\subsection{Determination of Hydration Characteristics}

Water absorption (WAI) and solubility (WSI) indices: Water absorption and solubility indices were determined according to the methods described by Anderson et al. [27] and Jin et al. [28] as modified by Onwulata et al. [29]. Extruded foods were grounded and sifted through a $210 \mu \mathrm{m}$ sieve and $1.0 \mathrm{~g}$ taken and placed in a centrifuge tube and $10 \mathrm{ml}$ distilled water added. After standing for 15 minutes and shaking every 5 minutes interval, the samples were centrifuged for 15 minutes at $100 \mathrm{rpm}$. The supernatant was decanted and the weight gain in the 
gel was recorded. WAI was calculated as the weight gain by the dry gel weight (Equation (1)). The supernatant were dried overnight at $90^{\circ} \mathrm{C}$ and WSI determined as weight of dried supernatant divided by the weight of dry sample (Equation (2))

$$
\begin{gathered}
\operatorname{WAI}(g)=\frac{\text { Weight of sediment }}{\text { Weight of dry solid }} \\
\operatorname{WSI}(g)=\frac{\text { Weight of disolved solid in supernatant }}{\text { Weight of dry solid }} .
\end{gathered}
$$

\subsection{Proximate Composition Determination}

Proximate composition (crude protein, ash, fibre, and fat contents) were determined using the methods 920.05, 923.03, 963.09 and 920.85 respectively of Association of Analytical Chemists [30], while moisture content was determined by the standard oven method where ten grams $(10 \mathrm{~g})$ of sample $\left(W_{i}\right)$ were dried in an oven at $105^{\circ} \mathrm{C}$ for 72 hours, after which the samples were reweighed to determine the final weight $\left(W_{f}\right)$. The percentage moisture content was then calculated using Equation (3). Carbohydrate was calculated by difference (Equation (4)).

$$
\begin{gathered}
\text { Moisture content }(\%)=\left[\left(W_{i}-W_{f}\right) / W_{i}\right] \times 100 \\
\text { Carbohydrate }(\%)=100-(\% \text { Moisture }+\% \text { Protein }+\% \text { Lipid }+\% \text { Ash }) .
\end{gathered}
$$

Calorie value was calculated using the Atwater conversion factor system, where $17 \mathrm{Kj} / \mathrm{g}(4.0 \mathrm{Kcal} / \mathrm{g})$ for protein, $37.0 \mathrm{Kj} / \mathrm{g}(9.0 \mathrm{kcal} / \mathrm{g})$ for fat and $17.0 \mathrm{Kj} / \mathrm{g}(4.0$ $\mathrm{kcal} / \mathrm{g}$ ) for carbohydrate were used as conversion factors.

\subsection{Experimental Design and Statistical Analysis}

RSM in a three (3) factors CCRD [31] consisting of 20 experiments (8 factorial points, 6 axial points and 6 central point) ( Table 2 ) and five levels combinations coded $-1.68,-1,0,+1$, and +1.68 were used to study the effects of extruder barrel temperature $\left(X_{1}, 100^{\circ} \mathrm{C}-140^{\circ} \mathrm{C}\right)$, feed moisture content $\left(X_{2}, 15-25 \mathrm{~g} / 100 \mathrm{~g}\right.$ sample) and feed soybean composition $\left(X_{3}, 8-24 \mathrm{~g} / 100 \mathrm{~g}\right.$ sample) (Table 1$)$ on the hydration and proximate composition of the extruded foods. Experimental data were subjected to regression analysis using MINITAB 14.13 to model the response factors as a mathematical function of a few continuous factors. Each response $(Y)$ was represented by a mathematical equation that correlates the response surfaces.

$$
\begin{aligned}
Y= & \beta_{o}+\beta_{1} X_{1}+\beta_{2} X_{2}+\beta_{3} X_{3}+\beta_{11} X_{1}^{2}+\beta_{22} X_{2}^{2}+\beta_{33} X_{3}^{2} \\
& +\beta_{12} X_{1} X_{2}+\beta_{13} X_{1} X_{3}+\beta_{23} X_{2} X_{3}+\varepsilon .
\end{aligned}
$$

The model developed for each response was examined for significance, for lack of fit, while 3D response surface plot was designed after removal of the non-significant terms with the same software. Adequacy of the model was also investigated by the examination of residuals [32]. Statistical analysis was carried out using MINITAB 14.13. Hydration and proximate data were analyzed using 
ANOVA and Fishers tests to evaluate if each term has a significant effect ( $p \leq$ 0.05 ), while the optimum level of each variables were obtained by graphical and numerical optimization analysis.

\section{Results and Discussion}

\subsection{Response Surface Methodology and Central Composite Design}

The effects of extruder barrel temperature, feed moisture content and feed blend composition on the quality characteristics of rice-soybean extruded food were studied using data generated from central composite rotatable experimental design (CCRD) (Table 1). The three independent variables were coded $X_{1}, X_{2}$ and $X_{3}$ respectively. Preliminary experiment indicated that minimum feed moisture content, soybean composition and process temperature for proper operation were $11.59 \mathrm{~g} / 100 \mathrm{~g}, 2.55$ soybean $/ 100 \mathrm{~g}$ rice flour and $86.36^{\circ} \mathrm{C}$ barrel temperature. Based on these results, a central composite rotatable design was formed with five levels of variation of temperature $\left(86.36^{\circ} \mathrm{C}, 100^{\circ} \mathrm{C}, 120^{\circ} \mathrm{C}, 140^{\circ} \mathrm{C}\right.$, and $\left.153.64^{\circ} \mathrm{C}\right)$, feed composition $(2.55 \%, 8 \%, 16 \%, 24 \%$, and $29.45 \%)$ and moisture content (11.59\%, $15 \%, 20 \%, 25 \%$, and $28.41 \%)$. The experimental matrix is shown in Table 1. The five experimental units formed a 20 full factorial design whereas 17 experimental runs were used with run 15 repeated three times (Table 2). Regression analysis of MINITAB 14.13 fitted the results to second order polynomial model (Equation (5)). The experimental and predicted results of the application of RSM and CCRD to the production of rice-soybean extruded foods in terms of functional and proximate compositions are presented in Table 3 and Table 4 respectively.

\subsection{Effect of Process Variables on Hydration Characteristics}

\subsubsection{Effect of Extrusion Variables on Dispersion Index (DI)}

The dispersibility attributes of extrudated foods is its ability to be wet without the formation of lumps, with simultaneous disintegration of agglomerates in aqueous solution. The most dispersed sample (98.16\%) was obtained at $140^{\circ} \mathrm{C}$ BRT, $25 \mathrm{~g} / 100 \mathrm{~g} \mathrm{FMC}$ and $24 \mathrm{~g} / 100 \mathrm{~g}$ soybean composition and the lowest (96.99\%) at $100^{\circ} \mathrm{C}$ BRT, $15 \mathrm{~g} / 100 \mathrm{~g}$ FMC and $24 \mathrm{~g} / 100 \mathrm{~g}$ FSC. DI seems to decrease with decreasing extrusion temperature and feed moisture composition, while soybean addition did not show any effect on the dispersibility. Similar results were reported by Almeida-Dominguez et al. [33] and Kone and Launay [34]. Molecular

Table 1. Process variables and their coded and natural levels in central composite design for $\mathrm{k}=3$.

\begin{tabular}{|c|c|c|c|c|c|c|c|}
\hline \multirow{2}{*}{ Independent variables } & \multirow{2}{*}{ Unit } & \multirow{2}{*}{ Symbol } & \multicolumn{5}{|c|}{ Variable levels } \\
\hline & & & $-\alpha$ & Low & Medium & High & $+\alpha$ \\
\hline & & & -1.682 & -1 & 0 & +1 & +1.682 \\
\hline Barrel temperature & ${ }^{\circ} \mathrm{C}$ & $X_{1}$ & 86.36 & 100.00 & 120.00 & 140.00 & 153.64 \\
\hline Feed moisture content & $\%(g / 100 g)$ & $X_{2}$ & 11.59 & 15.00 & 20.00 & 25.00 & 28.41 \\
\hline Feed soybean composition & $\%(g / 100 g)$ & $X_{3}$ & 2.55 & 8.00 & 16.00 & 24.00 & 29.45 \\
\hline
\end{tabular}


Table 2. Central composite rotatable design matrix and variable combinations for experimental runs.

\begin{tabular}{|c|c|c|c|c|c|c|}
\hline \multirow{3}{*}{ Run } & \multicolumn{6}{|c|}{ Coded and natural forms of variables } \\
\hline & \multicolumn{2}{|c|}{$\operatorname{BRT}\left({ }^{\circ} \mathrm{C}\right)\left(X_{1}\right)$} & \multicolumn{2}{|c|}{$\operatorname{FMC}(\mathrm{g} / 100 \mathrm{~g})\left(X_{2}\right)$} & \multicolumn{2}{|c|}{$\mathrm{FSC}(\mathrm{g} / 100 \mathrm{~g})\left(X_{3}\right)$} \\
\hline & Coded & Un-coded & Coded & Un-coded & Coded & Un-coded \\
\hline 1 & -1 & 100.00 & -1 & 15.00 & -1 & 8.00 \\
\hline 2 & 1 & 140.00 & -1 & 15.00 & -1 & 8.00 \\
\hline 3 & -1 & 100.00 & 1 & 25.00 & -1 & 8.00 \\
\hline 4 & 1 & 140.00 & 1 & 25.00 & -1 & 8.00 \\
\hline 5 & -1 & 100.00 & -1 & 15.00 & 1 & 24.00 \\
\hline 6 & 1 & 140.00 & -1 & 15.00 & 1 & 24.00 \\
\hline 7 & -1 & 100.00 & 1 & 25.00 & 1 & 24.00 \\
\hline 8 & 1 & 140.00 & 1 & 25.00 & 1 & 24.00 \\
\hline 9 & -1.682 & 86.36 & 0 & 20.00 & 0 & 16.00 \\
\hline 10 & 1.682 & 153.64 & 0 & 20.00 & 0 & 16.00 \\
\hline 11 & 0 & 120.00 & -1.682 & 11.59 & 0 & 16.00 \\
\hline 12 & 0 & 120.00 & 1.682 & 28.41 & 0 & 16.00 \\
\hline 13 & 0 & 120.00 & 0 & 20.00 & -1.682 & 2.55 \\
\hline 14 & 0 & 120.00 & 0 & 20.00 & 1.682 & 29.45 \\
\hline 15 & 0 & 120.00 & 0 & 20.00 & 0 & 16.00 \\
\hline 16 & 0 & 120.00 & 0 & 20.00 & 0 & 16.00 \\
\hline 17 & 0 & 120.00 & 0 & 20.00 & 0 & 16.00 \\
\hline
\end{tabular}

$\mathrm{BRT}=$ Barrel temperature, FMC $=$ Feed moisture content, FSC $=$ Feed soybean composition. Duplicate runs were carried out at all design point and average recorded. The experimental runs were randomized. Sample 17 is a mean of four experimental runs.

dispersion of starch-based extruded foods was affected by moisture content and temperature during processing. Jackson et al. [35] also observed relatively low dispersion at temperature slightly higher than starch gelatinization temperature. This justifies the increased dispersion of extrudates at higher temperature.

\subsubsection{Effect of Extrusion Variables on WAI and WSI}

The observed and predicted values of the WAI and WSI are presented in Table 3. The observed mean values for WAI ranged from 6.13 to $7.28 \mathrm{~g} / \mathrm{g}$ for samples 5 and 7 representing $100^{\circ} \mathrm{C}$ extrusion temperature, $15 \% \mathrm{FMC}$ and $24 \%$ feed soybean composition (FBC) and $100^{\circ} \mathrm{C}$ BRT, 25\% FMC and $24 \% \mathrm{FBC}$ respectively. From these results it is clear that there is an inverse relationship between dispersion and WAI, while addition of soybean did not significantly alters the WAI value (Table 3), barrel temperature and feed moisture content on the other hands seems to be the main processing variable affecting WAI. Similar result was reported by Ding et al. [15]. Water absorption index (WAI) is the measure of the volume occupied by food materials after swelling in excess water, which 
maintains the integrity of foods in aqueous dispersion, while water solubility index (WSI) is the measure of the degree of starch degradation during food processing which is reflected in the amount of polysaccharides from starch component. WSI therefore is a measure of molecular degradation and molecule solubility in water during preparation.

The WSI value varied between 8.31 and 8.93 in samples 13 and 7 respectively (Table 3). The highest value was recorded in sample extruded under $100^{\circ} \mathrm{C}$ BRT, $25 \%$ FMC and $24 \%$ soybean composition conditions, and the least value observed in sample extruded at $120^{\circ} \mathrm{C} \mathrm{BRT}$ and $20 \% \mathrm{FMC}$ and $2.6 \%$ soybean blend. Increasing barrel temperature and decreasing feed moisture and blend compositions during extrusion exercise seems to favor WSI characteristics of extrudates. This observation may probably be as a result of fact that during extrusion cooking, water is absorbed by feed material and at high temperature, favors the degradation of starchy component, hence increase the amount of small molecules in the final product. Conway [36], Artz et al. [37] and Badrie and Mellows [38] reported similar observation, where they all agree that at high temperature and

Table 3. Observed and predicted values of the hydration characteristics of the extruded foods.

\begin{tabular}{|c|c|c|c|c|c|c|}
\hline \multirow{3}{*}{ Experimental runs } & \multicolumn{6}{|c|}{ Hydration characteristics } \\
\hline & \multicolumn{2}{|c|}{ Dispersibility (\%) } & \multicolumn{2}{|c|}{ Water absorption } & \multicolumn{2}{|c|}{ Water solubility } \\
\hline & Observed & Predicted & Observed & Predicted & Observed & Predicted \\
\hline 1 & 97.41 & 97.39 & 6.45 & 6.51 & 8.39 & 8.38 \\
\hline 2 & 97.57 & 97.56 & 7.03 & 7.05 & 8.67 & 8.67 \\
\hline 3 & 97.49 & 97.50 & 6.52 & 6.54 & 8.37 & 8.36 \\
\hline 4 & 98.14 & 98.15 & 6.18 & 6.20 & 8.49 & 8.61 \\
\hline 5 & 98.16 & 98.13 & 6.13 & 6.12 & 8.71 & 8.69 \\
\hline 6 & 97.59 & 97.57 & 6.64 & 6.62 & 8.37 & 8.38 \\
\hline 7 & 97.07 & 97.08 & 7.28 & 7.27 & 8.93 & 8.95 \\
\hline 8 & 96.99 & 97.00 & 6.88 & 6.88 & 8.53 & 8.59 \\
\hline 9 & 97.41 & 97.42 & 6.73 & 6.73 & 8.44 & 8.45 \\
\hline 10 & 97.48 & 97.49 & 6.88 & 6.86 & 8.42 & 8.40 \\
\hline 11 & 97.51 & 97.65 & 6.40 & 6.39 & 8.74 & 8.74 \\
\hline 12 & 97.28 & 97.26 & 6.66 & 6.64 & 8.93 & 8.90 \\
\hline 13 & 97.96 & 97.96 & 6.47 & 6.44 & 8.31 & 8.37 \\
\hline 14 & 97.61 & 97.62 & 6.68 & 6.69 & 8.63 & 8.62 \\
\hline 15 & 97.82 & 97.87 & 6.28 & 6.29 & 8.53 & 8.59 \\
\hline 16 & 97.81 & 97.86 & 6.31 & 6.30 & 8.55 & 8.60 \\
\hline 17 & 97.83 & 97.87 & 6.28 & 6.29 & 8.54 & 8.59 \\
\hline Mean & 97.60 & 97.61 & 6.58 & 6.58 & 8.56 & 8.58 \\
\hline CV (\%) & 0.338 & 0.341 & 4.801 & 4.762 & 2.166 & 2.081 \\
\hline
\end{tabular}


low moisture, long chain molecules of food materials are broken down during extrusion to simple soluble molecules which increase WSI.

\subsection{Effect of Process Variables on the Proximate Composition}

\subsubsection{Effect of Process Variables on Moisture Content of Extrudate}

The observed and predicted proximate composition results for rice-soybean based extrudates are presented in Table 4 . The moisture content of the extrudates varied between $0.08 \%$ and $1.31 \%$. These results demonstrate that product moisture content decrease with increasing extrusion temperature.

\subsubsection{Effect of Process Variables on Protein Content of Extrudate}

The highest protein content of $28.30 \%$ was observed in run 13 , representing $120^{\circ} \mathrm{C}$ BRT, 20\% FMC and 2.6\% FBC, while the lowest value of $21.93 \%$ was recorded in run $9\left(86.4^{\circ} \mathrm{C} \mathrm{BRT}, 20 \% \mathrm{FMC}\right.$ and $\left.8 \% \mathrm{FBC}\right)$.

The addition soybean flour to the rice to produce extruded starch-based food increases protein content, probably due to the increase in the number of sites for crosslinking, but this shortens the starch matrix, resulting in tough, nonexpanded crusts, similar result was reported by Martinez-Serna and Villota (1992). Generally, EC results in significant decrease in protein content of extruded materials (Sobota et al., 2010). The reduction in protein content may be attributed to reduction in nitrogen content as a result of the effect of the formation of isopeptide bonds between $\varepsilon$-amine groups of lysine and amine groups of asparagines or glutamine, accompanied by the release of ammonia (Stanley and Baker, 2002).

\subsubsection{Effect of Process Variables on Lipid Content of Extrudate}

The lipid content remain within a close range of $3.20 \%$ and $4.36 \%$ for runs 3 and 15 representing $100^{\circ} \mathrm{C}$ BRT, $25 \% \mathrm{FMC}$ and $8 \% \mathrm{FBC}$ and $120^{\circ} \mathrm{C}$ barrel temperature, $20 \%$ feed moisture and $16 \%$ soybean. The high lipid content was observed when soybean was added to the rice flour may be because soybean is an oil crop, though the value is not as high as $40 \%-42 \%$ often quoted for soybean seeds. Lipid levels over 5\% - 6\% impair extruder performance (Camire, 2001).

The presence of soybean protein in the feed formulation creates a favorablecondition for the formation of starch-lipid and lipid-protein complexes, thereby resulting in varying levels of fat contents. Sabota et al. (2010) reported that in a sample containing $20 \%$ of wheat bran and extruded at a die diameter of $4.2 \mathrm{~mm}$, the degree of fat complex formation was $70.77 \%$. As the content of wheat bran in the formulation increased, there was a concurrent reduction in the complex of fat reaching $29.63 \%$ at $80 \%$ bran content. They also report that similar effect of lipid bonding may be exerted due to change in feed moisture content. The fat content of extrudate increased considerably with increasing moisture content of the feed materials. Fat increased from $0.62 \%$ at feed moisture content of $14 \%$ to $0.92 \%$ at $29 \%$ moisture content (Sabota et al., 2010) similar to what is seen in this study. 


\subsubsection{Effect of Process Variables on Fibre Content of Extrudate}

The fiber content of the rice-soybean extrudates ranged from $0.77 \%-3.22 \%$ for runs 10 and 8 representing $153.6^{\circ} \mathrm{C}$ barrel temperature, $20 \%$ feed moisture and $16 \%$ soybean and $140^{\circ} \mathrm{C}$ barrel temperature, $25 \%$ feed moisture and $24 \%$ soybean. Increasing soybean content and reducing extrusion temperature favorsfiber recovery. For the crude fiber content of rice-soybean extrudates, the highest value $(0.62 \%)$ was observed in sample 2 extruded under extrusion condition of $140^{\circ} \mathrm{C}$ barrel temperature, $15 \%$ feed moisture and $8 \%$ soybean and the least value of 0.35 was observed in sample $14\left(120^{\circ} \mathrm{C}\right.$ barrel temperature, $20 \%$ feed moisture and $29.5 \%$ soybean).

Varo et al. (1983) reported insignificant changes in fibre content of twin- screw extruded wheat flour and whole-wheat meal at $161^{\circ} \mathrm{C}-180^{\circ} \mathrm{C}$ process temperature and $15 \%$ feed moisture. Non-significant change was also found in dietary fibre content when wheat was extruded under milder conditions, but the fibre present became slightly more soluble (Mendez-Garcia et al., 2011). On the other hand, an increase in dietary fibre content of wheat flours with increasing product temperature $\left(150^{\circ} \mathrm{C}-200^{\circ} \mathrm{C}\right)$ was reported. This is similar to results of this study.

\subsubsection{Effect of Process Variables on Carbohydrate Content of Extrudate}

The carbohydrates and caloric values for rice-soybean extrudates as influence by the three independent variables varied from $66.30 \%-73.00 \%$, and 403.97 $416.08 \mathrm{kcal} / 100 \mathrm{~g}$ respectively. The highest and least values of carbohydrate were recorded in samples 13 and 10 representing extrusion conditions $120^{\circ} \mathrm{C}$ barrel temperature, $20 \%$ feed moisture and $2.6 \%$ soybean and $153.6^{\circ} \mathrm{C}$ barrel temperature, and $20 \%$ feed moisture and $16 \%$ soybean.

Carbohydrates contents of foods range from simple sugars to more complex molecules, like starch and fibre. Several researchers have reported sugar losses during EC (Noguchi et al., 1982; Camire et al., 1990). This may probably be as a result of the conversion of sucrose into reducing sugars, and loss of these reducing sugars during Maillard reactions with proteins.

\subsubsection{Effect of Process Variables on Caloric Value of Extrudate}

While the highest and lowest values for caloric values were seen in samples 8 and 15 produced under independent variable combination of $140^{\circ} \mathrm{C}$ barrel temperature, $25 \%$ feed moisture and $24 \%$ soybean for sample 8 and $120^{\circ} \mathrm{C}$ barrel temperature, $20 \%$ feed moisture and $16 \%$ soybean for sample 15 . The caloric value of 403.97 - $416.08 \mathrm{kcal} / 100 \mathrm{~g}$ for rice-soybean composite flour extrudates is higher than $345 \mathrm{kcal} / 100 \mathrm{~g}$ often reported for milled rice. The addition of these legumes improves the protein, lipid and other compositions of the final product, hence its contribution to increased calories per $100 \mathrm{~g}$.

\subsection{Estimation and Validation of the Model Parameters for Hydration Characteristics}

By applying multiple regression analysis on the experimental data (Table 4 and Table 5), the model fitted for the response variables could be expressed by the 
Table 4. Observed and predicted mean effects of barrel temperature, feed moisture content and feed composition on the proximate composition of rice-soybean based extrudates.

\begin{tabular}{|c|c|c|c|c|c|c|c|c|c|c|c|c|c|c|}
\hline \multirow[t]{2}{*}{ Run } & \multicolumn{2}{|c|}{$\begin{array}{c}\text { Moisture } \\
\text { Content (\%) }\end{array}$} & \multicolumn{2}{|c|}{$\begin{array}{c}\text { Lipid content } \\
(\%)\end{array}$} & \multicolumn{2}{|c|}{$\begin{array}{c}\text { Crude Protein } \\
(\%)\end{array}$} & \multicolumn{2}{|c|}{$\begin{array}{c}\text { Fibre } \\
(\%)\end{array}$} & \multicolumn{2}{|c|}{$\begin{array}{c}\text { Ash content } \\
(\%)\end{array}$} & \multicolumn{2}{|c|}{$\begin{array}{c}\text { Carbohydrate } \\
(\%)\end{array}$} & \multicolumn{2}{|c|}{$\begin{array}{c}\text { Energy } \\
\text { (Kcal/100g) }\end{array}$} \\
\hline & OBS & PDT & OBS & PDT & OBS & PDT & OBS & PDT & OBS & PDT & OBS & PDT & OBS & PDT \\
\hline 1 & 1.310 & 1.297 & 3.220 & 3.338 & 25.800 & 25.906 & 0.960 & 1.372 & 0.480 & 0.435 & 69.540 & 68.794 & 410.340 & 409.392 \\
\hline 2 & 0.700 & 0.693 & 3.410 & 3.536 & 25.220 & 25.318 & 0.980 & 0.663 & 0.620 & 0.593 & 69.770 & 69.920 & 410.650 & 412.529 \\
\hline 3 & 0.810 & 0.817 & 3.200 & 3.321 & 24.680 & 24.596 & 1.180 & 0.897 & 0.560 & 0.513 & 70.380 & 70.578 & 409.040 & 410.684 \\
\hline 4 & 0.470 & 0.451 & 3.880 & 3.889 & 25.110 & 25.128 & 1.000 & 1.030 & 0.500 & 0.446 & 69.510 & 69.422 & 413.400 & 413.606 \\
\hline 5 & 0.660 & 0.626 & 4.000 & 4.102 & 23.000 & 22.941 & 1.080 & 0.837 & 0.390 & 0.364 & 71.130 & 71.388 & 414.120 & 415.521 \\
\hline 6 & 0.410 & 0.385 & 3.500 & 3.530 & 23.020 & 23.081 & 1.120 & 1.163 & 0.500 & 0.487 & 71.860 & 71.782 & 411.020 & 410.962 \\
\hline 7 & 0.330 & 0.319 & 3.820 & 3.829 & 23.620 & 23.465 & 1.380 & 1.427 & 0.500 & 0.472 & 70.680 & 70.646 & 411.580 & 411.253 \\
\hline 8 & 0.310 & 0.315 & 3.610 & 3.627 & 24.810 & 24.663 & 3.220 & 2.578 & 0.400 & 0.370 & 67.880 & 68.757 & 403.970 & 406.479 \\
\hline 9 & 1.090 & 1.040 & 3.650 & 3.478 & 21.930 & 21.982 & 0.930 & 0.774 & 0.510 & 0.490 & 72.890 & 73.156 & 412.490 & 412.118 \\
\hline 10 & 0.580 & 0.529 & 3.580 & 3.474 & 22.120 & 22.494 & 0.770 & 1.145 & 0.530 & 0.544 & 73.000 & 72.515 & 412.700 & 410.741 \\
\hline 11 & 0.750 & 0.742 & 3.890 & 3.685 & 24.140 & 24.005 & 1.020 & 0.909 & 0.500 & 0.477 & 70.450 & 70.705 & 413.370 & 412.724 \\
\hline 12 & 0.340 & 0.281 & 3.810 & 3.752 & 24.140 & 24.286 & 1.360 & 1.699 & 0.400 & 0.444 & 70.220 & 69.661 & 411.730 & 410.041 \\
\hline 13 & 0.830 & 0.791 & 3.880 & 3.657 & 28.300 & 28.168 & 1.080 & 0.987 & 0.440 & 0.450 & 66.300 & 66.622 & 413.320 & 412.397 \\
\hline 14 & 0.140 & 0.112 & 4.120 & 4.080 & 25.100 & 25.283 & 1.560 & 1.852 & 0.350 & 0.326 & 68.870 & 68.244 & 412.960 & 411.557 \\
\hline 15 & 0.080 & 0.083 & 4.360 & 4.367 & 24.240 & 24.211 & 1.020 & 0.964 & 0.410 & 0.394 & 69.970 & 69.981 & 416.080 & 416.432 \\
\hline
\end{tabular}

OBS $=$ Observed, $\mathrm{PRD}=$ Predicted, $X_{1}=$ Barrel temperature, $X_{2}=$ Feed moisture content, $X_{3}=$ Feed composition. Duplicate runs were carried out all design point and average recorded. The experimental runs were randomized.

Table 5. Estimated regression equation coefficients for response variables (proximate composition) in rice-soybean blends.

\begin{tabular}{|c|c|c|c|c|c|c|c|c|c|c|}
\hline Coefficient & DI & WAI & WSI & Moisture & Lipid & Protein & Fiber & Ash & $\mathrm{CHO}$ & Energy \\
\hline Constant & $88.999^{* *}$ & $10.632^{* *}$ & $5.858^{* *}$ & $16.6771^{*}$ & $-12.2626^{*}$ & $15.1346^{*}$ & $11.5455^{*}$ & 1.0045 & $84.3212^{*}$ & $288.547^{*}$ \\
\hline \multicolumn{11}{|c|}{ Linear coefficient } \\
\hline$X_{1}$ & $0.0837^{* *}$ & $-0.0613^{* *}$ & $0.0519^{* *}$ & $-0.1773^{*}$ & $0.1986^{*}$ & $0.3536^{*}$ & -0.0607 & -0.0140 & $-0.4826^{*}$ & $1.244^{*}$ \\
\hline$X_{2}$ & $0.1870^{* *}$ & $0.0362^{* *}$ & $-0.1352^{* *}$ & $-0.3585^{*}$ & $0.2851^{*}$ & $-0.4657^{*}$ & $-0.4996^{*}$ & 0.0250 & $0.7613^{*}$ & $3.318^{*}$ \\
\hline$X_{3}$ & $0.2819^{* *}$ & $-0.1714^{* *}$ & $0.1054^{* *}$ & $-0.1799^{*}$ & $0.2800^{*}$ & $-0.9057^{*}$ & $-0.3755^{*}$ & -0.0007 & $0.9640^{*}$ & $2.894^{*}$ \\
\hline \multicolumn{11}{|c|}{ Quadratic coefficient } \\
\hline$X_{1}^{2}$ & $-0.0004^{* *}$ & $0.0005^{* *}$ & $-0.00015^{* *}$ & $0.0006^{*}$ & $-0.0008^{*}$ & $-0.0017^{*}$ & 0.0000 & $0.0001^{*}$ & $0.0025^{*}$ & $-0.004^{*}$ \\
\hline$X_{2}^{2}$ & $-0.0059^{* *}$ & $0.0033^{* *}$ & $0.00329^{* *}$ & $0.0061^{*}$ & $-0.0092^{*}$ & -0.0009 & 0.0048 & $0.0009^{*}$ & 0.0029 & $-0.071^{*}$ \\
\hline$X_{3}^{2}$ & $-0.0004^{*}$ & $0.0016^{* *}$ & $-0.00054^{* *}$ & $0.0020^{*}$ & $-0.0028^{*}$ & $0.0139^{*}$ & 0.0025 & -0.00003 & $-0.0141^{*}$ & $-0.025^{*}$ \\
\hline \multicolumn{11}{|c|}{ Interaction coefficient } \\
\hline$X_{12}$ & $0.0012^{* *}$ & $-0.0022^{* *}$ & -0.00011 & $0.0006^{*}$ & $0.0009^{*}$ & $0.0028^{*}$ & $0.0021^{*}$ & $-0.0006^{*}$ & $-0.0057^{*}$ & -0.001 \\
\hline$X_{13}$ & $-0.0011^{* *}$ & -0.0001 & $-0.00094^{* *}$ & $0.0006^{*}$ & $-0.0012^{*}$ & $0.0010^{*}$ & $0.0016^{*}$ & -0.00005 & -0.0011 & $-0.012^{*}$ \\
\hline$X_{23}$ & $-0.0073^{* *}$ & $0.0070^{* *}$ & $0.00168^{* *}$ & $0.0011^{*}$ & -0.0016 & $0.0115^{*}$ & $0.0067^{*}$ & 0.00019 & $-0.0158^{*}$ & $-0.035^{*}$ \\
\hline$R^{2}$ & 99.62 & 99.61 & 99.01 & 99.20 & 88.50 & 99.00 & 74.20 & 81.80 & 93.80 & 75.80 \\
\hline$R_{\mathrm{adj}}^{2}$ & 99.41 & 95.01 & 98.60 & 98.90 & 83.30 & 98.60 & 62.60 & 73.60 & 91.00 & 64.90 \\
\hline Lack-of-fit & NS & NS & NS & NS & NS & NS & NS & NS & NS & NS \\
\hline
\end{tabular}

${ }^{\mathrm{a}} Y=\beta_{o}+\beta_{1} X_{1}+\beta_{2} X_{2}+\beta_{3} X_{3}+\beta_{11} X_{1}^{2}+\beta_{22} X_{2}^{2}+\beta_{33} X_{3}^{2}+\beta_{12} X_{1} X_{2}+\beta_{13} X_{1} X_{3}+\beta_{23} X_{2} X_{3} ; X_{1}=$ Barrel temperature, $X_{2}=$ Feed Moisture content, $X_{3}=$ feed blend composition, ${ }^{*}$ and ${ }^{* *}=$ significant at $5 \%$ and $1 \%$ level of probability respectively. 
following quadratic polynomial equations in the form of coded values (Equations ((6)-(8))) for hydration characteristics.

\section{Dispersion index}

$$
\begin{aligned}
& 88.9988+0.0837 X_{1}+0.1870 X_{2}+0.2819 X_{3}-0.0004 X_{1}^{2}-0.0059 X_{2}^{2} \\
& -0.0004 X_{3}^{2}+0.0012 X_{1} X_{2}-0.0011 X_{1} X_{3}-0.0073 X_{2} X_{3}\left(R^{2}=99.01, R_{\mathrm{adj}}^{2}=98.60\right)
\end{aligned}
$$

\section{Water absorption index}

$$
\begin{aligned}
& 10.632-0.0613 X_{1}+0.0362 X_{2}-0.1714 X_{3}+0.0005 X_{1}^{2}+0.0033 X_{2}^{2} \\
& +0.0016 X_{3}^{2}-0.0022 X_{1} X_{2}-0.0011 X_{1} X_{3}+0.0007 X_{2} X_{3}\left(R^{2}=99.62, R_{\mathrm{adj}}^{2}=99.41\right)
\end{aligned}
$$

\section{Water solubility index}

$$
\begin{aligned}
& 5.8581+0.0519 X_{1}-0.1352 X_{2}+0.1054 X_{3}-0.00015 X_{1}^{2}+0.00329 X_{2}^{2} \\
& -0.0054 X_{3}^{2}-0.00011 X_{1} X_{2}-0.00094 X_{1} X_{3}+0.00168 X_{2} X_{3}\left(R^{2}=99.61, R_{\mathrm{adj}}^{2}=95.01\right) .
\end{aligned}
$$

Equation (6) indicates that at linear level, process variables $\left(X_{1}, X_{2}\right.$, and $\left.X_{3}\right)$ had positive effects on the dispersion. At quadratic level, all the variables had negative effect on the dispersion of the extrudate in water, while interaction between barrel temperature and feed soybean composition had negative effect. Table 5 is the ANOVA of the coefficient of regression. From this result, there is a significant $(p<0.05)$ interaction between the process variables. Significant interaction indicates that the level of one of the interaction variables can be increased while that of other decreased for constant value of the response (Adeyanju et al., 2016a, 2016b). For WAI, addition of soybean at linear level to the formulation resulted in reduction of response (Equation (7)). While interaction of barrel temperature and feed moisture content were positive, indicating antagonistic effect on response. There was negative contribution of barrel temperature to WSI, indicating that as the temperature increase, WSI also decreases (Equation (8)).

The analysis of variance (ANOVA) for the regression models representing the relationship between independent variables and hydration characteristics in terms of DI, WAI and WSI is presented in Table 6. The coefficient of determination $\left(R^{2}\right) 99.01 \%, 99.62 \%$ and $99.61 \%$ for the DI, WAI and WSI respectively indicated that only $0.99 \%, 0.38 \%$ and $0.39 \%$ of the variability observed could not be explained by the fitted models. For a statistical model to better explain variability in response, it is important that the adjusted determination coefficient ( $R_{\text {adj }}^{2}$.) be close to $R^{2}$. As shown in Equations (6)-(8), $R^{2}$ was close to $R_{\text {adj }}^{2}$ and this confirmed that the models were highly significant and that the model could be used to navigate the design space. Koocheki et al. [39] reported that for a good fitted polynomial model, $R^{2}$ should not be less than $80 \%$, while Chauhan and Gupta [40] were of the opinion that $R^{2}$ greater than $75 \%$ is acceptable for multivariate system model. It is also important to take into consideration the fact that adding additional variable to the model will always increase $R^{2}$, regardless of whether the additional variable is statistically significant or not. Thus, a large $R^{2}$ does not always imply adequacy of the model. Adjusted $R^{2}$ is therefore 
the best measure as higher $R_{\text {adj }}^{2}$ indicated that non-significant terms have not been included in the model as observed in this study.

At the same time, relatively low values of coefficient of variation (CV) (Table 6) $(0.338,0.341$ and 4.801$)$ indicates a better precision and reliability of the experimental values. Lack-of-fit test also indicated non-significant $p$-value $(p<$ 0.05 ) for the hydration characteristics (Table 5). Non-significant lack-of-fit is desired as a significant test indicates that there may be contributions in the regression models that are not accounted for by the fitted models. Therefore, the models are quite adequate for the prediction of the system in the range of experimental variables.

\subsection{Estimation and Validation of the Model Parameters for Proximate Composition}

Seven predictive models (Equations (9)-(15)) were obtained as a result of fitting the second order polynomial of Equation (1) to experimental data for the effects of different combinations of extrusion process variables on the proximate composition. These predictive models were tested for adequacy and fitness by analyses of variance (ANOVA, Table 5). According to Myers and Montgomery [41] and Milán-Carrillo et al. [42], a satisfactory predictive model should have an adjusted $R^{2} \geq 0.80$, a significance level of $p<0.05$, coefficients of variance (CV) values $\leq 10 \%$, and lack of fit test non-significant; all these parameters could be used to decide whether the model satisfactorily predict the relationship between the independent and dependent variable. From this study, the adjusted $R^{2}$ for the predictive models are greater than $80 \%$ except for fibre (62.60\%), ash (73.60) and caloric value (64.90). These results are indication that only $1.1 \%$ moisture, $16.7 \%$ lipid, $1.4 \%$ protein, 37.4 fibre, $26.40 \%$ ash, $9.0 \%$ carbohydrate and $35.1 \%$ calorie variations are not accounted for by the model and therefore can satisfactorily predict optimum response in terms of proximate composition. The models were also having significant $\mathrm{p}$-value $(p<0.05)$ and the lack-of-fit test were non-significant $(p<0.05)$ (Table 5) indicative of the appropriateness of the models. The significance of each coefficients measured using p-value and F-value is listed in Table 5. The p-value of the models and coefficients are less than 0.0001 , which indicates that the model is significant and can be used to optimize the process variables $R^{2}$.

Moisture

$$
\begin{aligned}
& 16.677-0.1773 X_{1}-0.3585 X_{2}+-0.1799 X_{3}+0.0006 X_{1}^{2}+0.0061 X_{2}^{2} \\
& +0.002 X_{3}^{2}+0.0006 X_{1} X_{2}+0.0006 X_{1} X_{3}+0.0011 X_{2} X_{3}\left(R^{2}=99.20, R_{\text {adj }}^{2}=98.90\right)
\end{aligned}
$$

Lipid

$$
\begin{aligned}
& -12.2626+0.1896 X_{1}+0.2851 X_{2}+0.2800 X_{3}-0.0008 X_{1}^{2}-0.0092 X_{2}^{2} \\
& -0.0028 X_{3}^{2}+0.0009 X_{1} X_{2}-0.0012 X_{1} X_{3}-0.0016 X_{2} X_{3}\left(R^{2}=88.50, \mathrm{R}_{\text {adj. }}^{2}=83.30\right)
\end{aligned}
$$

Protein

$$
\begin{aligned}
& 15.1346+0.03536 X_{1}-0.4657 X_{2}-0.9057 X_{3}-0.0017 X_{1}^{2}-0.0009 X_{2}^{2} \\
& +0.0139 X_{3}^{2}+0.0028 X_{1} X_{2}+0.001 X_{1} X_{3}+0.0115 X_{2} X_{3}\left(R^{2}=99.00, R_{\mathrm{adj}}^{2}=98.60\right)
\end{aligned}
$$




\section{Fibre}

$$
\begin{aligned}
& 11.5455-0.0607 X_{1}-0.4996 X_{2}-0.3755 X_{3}+0.0048 X_{2}^{2}+0.0025 X_{3}^{2} \\
& +0.0021 X_{1} X_{2}+0.0016 X_{1} X_{3}+0.0067 X_{2} X_{3}\left(R^{2}=74.20, R_{\mathrm{adj}}^{2}=62.60\right)
\end{aligned}
$$

\section{Ash content}

$$
\begin{aligned}
& 0.0045-0.0140 X_{1}+0.02498 X_{2}-0.0007 X_{3}+0.00011 X_{1}^{2}+0.00094 X_{2}^{2}-0.00003 X_{3}^{2} \\
& -0.00056 X_{1} X_{2}-0.00005 X_{1} X_{3}+0.00019 X_{2} X_{3}\left(R^{2}=81.80, R_{\mathrm{adj}}^{2}=73.60\right)
\end{aligned}
$$

\section{Carbohydrate content}

$84.3212-0.4826 X_{1}+0.7613 X_{2}+9640 X_{3}+0.0025 X_{1}^{2}+0.0029 X_{2}^{2}-0.0141 X_{3}^{2}$

$-0.0057 X_{1} X_{2}-0.0011 X_{1} X_{3}-0.0158 X_{2} X_{3}\left(R^{2}=93.80, R_{\mathrm{adj}}^{2}=91.00\right)$

\section{Caloric value}

$$
\begin{aligned}
& 288.547+1.244 X_{1}+3.318 X_{2}+2.894 X_{3}-0.004 X_{1}^{2}-0.071 X_{2}^{2}-0.025 X_{3}^{2} \\
& -0.001 X_{1} X_{2}-0.012 X_{1} X_{3}-0.035 X_{2} X_{3}\left(R^{2}=75.80, R_{\mathrm{adj}}^{2}=64.90\right) .
\end{aligned}
$$

\subsection{Optimization of the Extrusion Process}

The 3D response surface plot of the effect of process variables on the hydration characteristics are presented in Figures 1-3 for DI, WAI and WSI respectively of rice-soybean extrudate. The $3 \mathrm{D}$ surface plots are graphical representation of regression equation and are very useful in judging the relationship between independent and dependent variables and also locating point of optimum conditions.

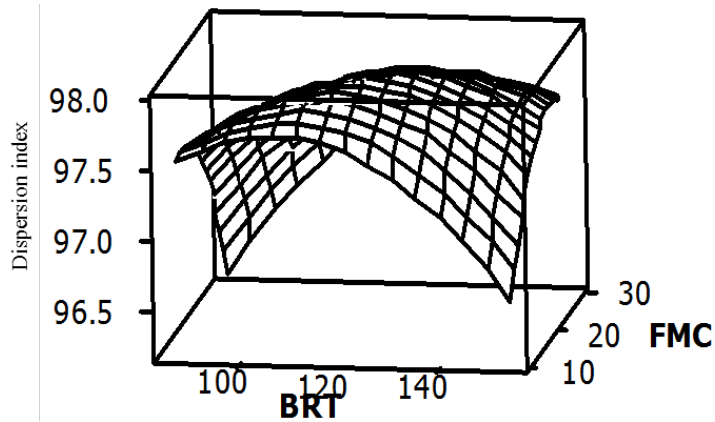

Figure 1. Response surface plot for the effect of barrel temperature versus feed moisture content on the dispersion index (\%) of rice-soybean extrudates.

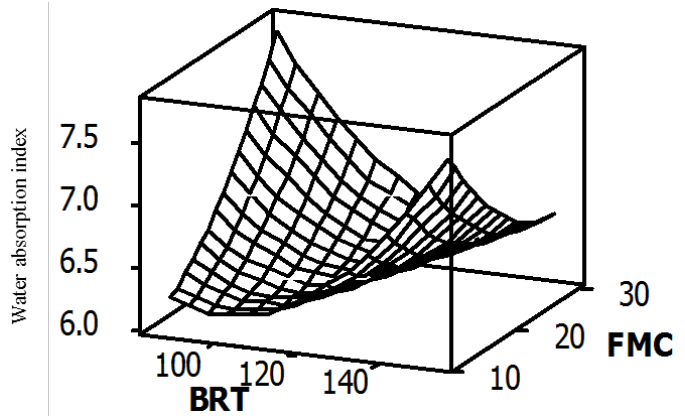

Figure 2. Response surface plot for the effect of barrel temperature versus feed soybean content on the water absorption index of rice-soybean extrudates. 


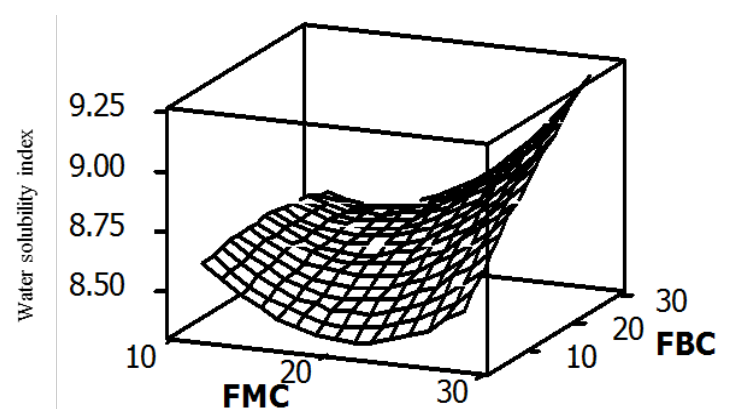

Figure 3. Response surface plot for the effect of barrel temperature versus feed soybean content on the water solubility index of rice-soybean extrudates.

In these plots, two variables are depicted in three-dimensional surface plot; the third variable is fixed at constant level. In this study, the response surfaces are typical for rice based products during extrusion and are indicative that the ranges of variables were chosen properly [43] and optimum DI and WAI are located between $120^{\circ} \mathrm{C}$ BRT and 20\% FMC (Figure 1 and Figure 2).

As shown in Figure 1 and Figure 2, at high barrel temperature and low moisture content, DI and WAI are significantly $(p \leq 0.05)$ reduced and at barrel temperature around $120^{\circ} \mathrm{C}$ optimum DI and WAI are attained. Feed moisture content and feed soybean composition significantly $(p \leq 0.05)$ affects DI value. Increase in fiber content as a result of the addition of soybean flour may be responsible for the reduction in DI value. Charunuch et al. [44] reported that fibre content of food reduce or delay swelling of granules thereby resulting in poor reconstitution in water and therefore lower dispersion. The flat surface plot for WSI (Figure 3) is an indication that the optimum WSI can be attained even when one of the variables is varied. At moisture content of about $10 \%$, the WSI decrease gradually as the FMC reaches $20 \%$ and steadily increases again as the moisture increases to about 30\% (Figure 3). While WSI index increased as the feed soybean content increase and reaches a maximum at about $28 \%$ feed soybean content (Figure 3). But the 3D for the WSI is rather symmetrical and flat near the optimum, indicating that the optimized values may not vary widely from the single variable conditions.

Beside the starch degradation at high temperature, low moisture and high shear force which results in the release of low molecular compounds, gelatinization and other related reactions have also been reported to occur during extrusion which may results in the formation of low molecular weight compounds, hence influencing water solubility behavior of the extrudates (Figures 1-3). Camire and Krumhar [45], Marzec and Lewecki [46] and Mesquita et al. [47] reported that protein denaturation, starch gelatinization and swelling of crude fiber content of feed during extrusion cooking could also be responsible for the variations of the WAI and WSI behavior in extruded materials as seen in this study. Uncovering of hydrophilic groups in extruded starch-protein materials by unfolding and loosing of biopolymers chains increases greater availability of simple soluble materials and easier penetration of structures by water molecules, thereby affecting WAI and WSI and indispersion. 
$3 \mathrm{D}$ response surface plots for the proximate composition are presented in Figures 4-7. The graphs are representations of regression equation as it relates to the relationship between the dependent and independent variables. The threedimensional representation of the response surfaces and generated by the model shows when two variables are depicted in three-dimensional surface plots, and the third variable is fixed at zero level.

As the feed moisture content increased, higher extrudate moisture was obtained due to the higher amount of water present in dough. While increasing processing temperature decrease product moisture content, the effect was only significant for high added moisture level. Similar results were reported by Badrie

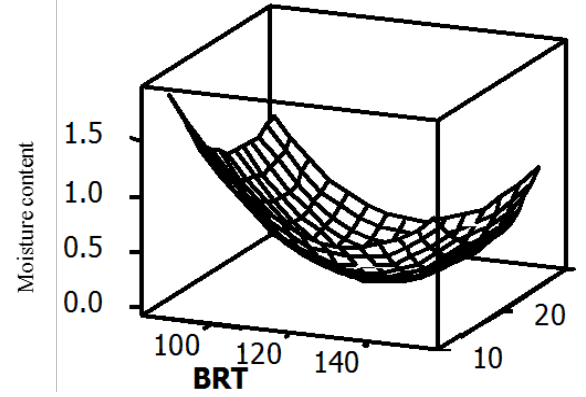

(a)

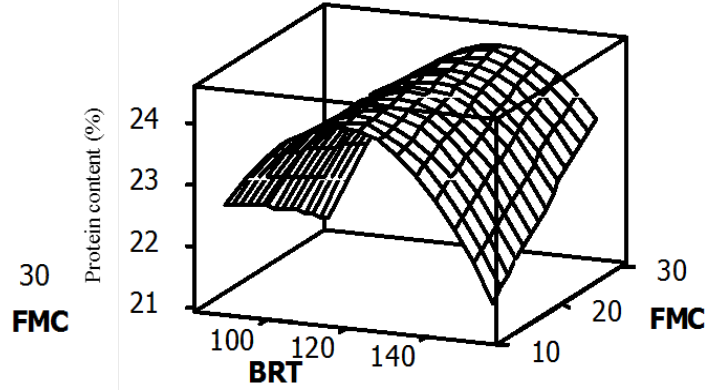

(b)

Figure 4. Response surface plot for the effect of barrel temperature versus feed moisture content on the moisture content (\%) (a) and protein (\%) (b) of rice-soybean extrudates.

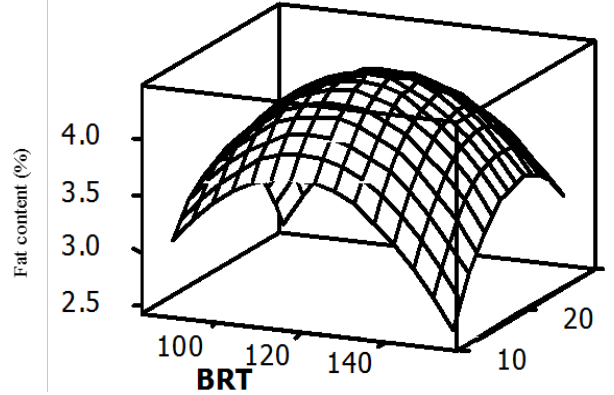

(a)

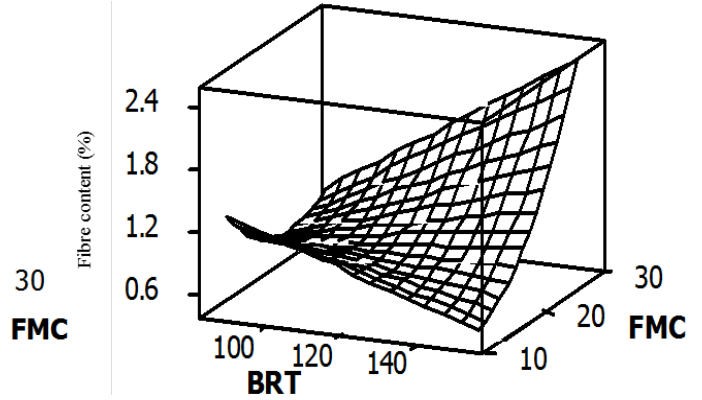

(b)

Figure 5. Response surface plot for the effect of barrel temperature versus feed moisture content on the fat content (\%) (a) and fibre (\%) (b) of rice-soybean extrudates.

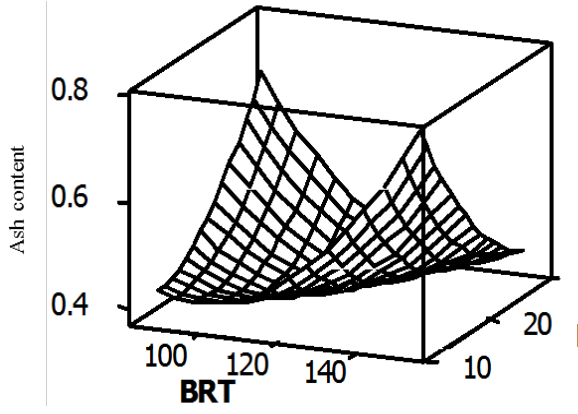

(a)

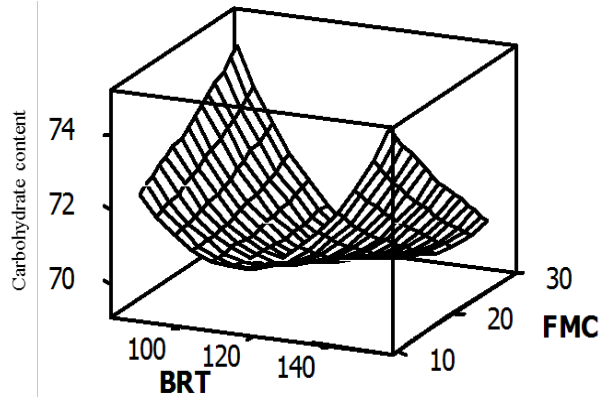

(b)

Figure 6. Response surface plot for the effect of barrel temperature versus feed moisture content on the ash content (\%) (a) and carbohydrate (\%) (b) of rice-soybean extrudates. 


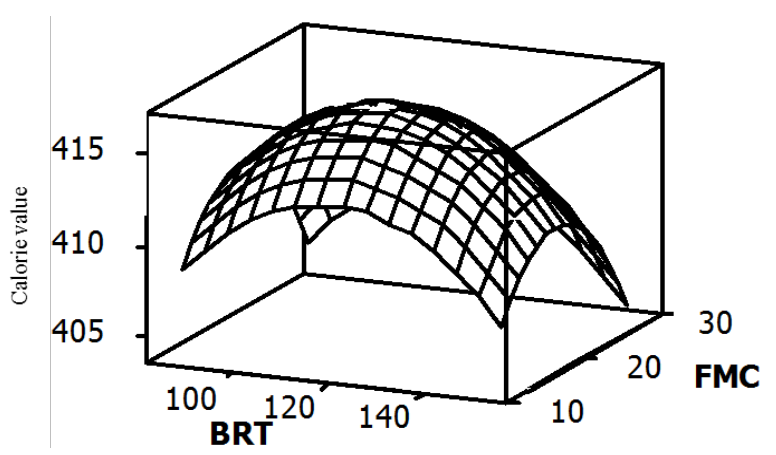

Figure 7. Response surface plot for the effect of barrel temperature versus feed moisture content on calorie value ( $\mathrm{kcal} / 100 \mathrm{~g})$ of rice-soybean extrudates.

and Mellowes [38] and attributed this increase in extrudate moisture content to the flash of water that happened as the product leaves the die. As indicated in Figure 5(a), the maximum extrudate fat level occurs at around $130^{\circ} \mathrm{C}$ barrel temperature and $20 \%$ feed moisture conditions. The fat content increased with increasing temperature, however, when the temperature reaches slightly above $130^{\circ} \mathrm{C}$, the effect of temperature significantly $(p \leq 0.05)$ decreased to its minimum level above $140^{\circ} \mathrm{C}$. But fat content increased as the feed moisture increased until it reaches its optimum around $20 \%$, then decreased as the moisture level increased above this percentage. It can be concluded that the lipid content of rice-soybean extrudates is almost primarily controlled by the barrel temperature and amount of legume. Based on the fitting model for the effects of process variables on the protein content of rice-soybean extrudates, the optimal process of the extruded foods protein content was optimized. The relationship between the independent variables and dependent variables (protein) is graphically represented by $3 \mathrm{D}$ surface plots (Figure 4 (b)). It depicted that the highest protein level could be achieved when temperature were set at around $120^{\circ} \mathrm{C}$ and feed moisture content of slightly above $20 \%$.

\subsection{Numerical Optimization of Process Variables}

MINITAB's Response Optimizer was used for simultaneous numerical optimization of the multiple responses, to search for a combination of independent variables levels that simultaneously satisfy the target requirement placed on each response and factors. Anuar et al. [48] and Gupta et al. [49] suggested that numerical optimization require that goals (i.e. None, Maximum, Minimum, Target or Range) should be set for the variables and response where all goals are combined into one desirable function. In this study, good sets of conditions that will meet all the goals, the independent variables (i) barrel temperature $\left(100^{\circ} \mathrm{C}\right.$ $140^{\circ} \mathrm{C}$ ), (ii) feed moisture content $\left(15-25 \mathrm{~g} \cdot 100 \mathrm{~g}^{-1}\right)$ and (iii) feed blend composition $\left(8-24 \mathrm{~g} \cdot 100 \mathrm{~g}^{-1}\right)$ were all set within range after preliminary experiment, while WAI, WSI, DI and protein score were set at 5 . Importance of score of a goal is within 1 to 5 and setting goal importance at 3 indicates that the variable is considered to be equally important, but set at 5 , the response target objective is to meet the objective of getting response at maximum level as applied in this 
study (Table 6).

By applying the desirability function, the best optimum independent variables for $X_{1}, X_{2}$ and $X_{3}$ were $120^{\circ} \mathrm{C}$ BRT, 20\% FMC, 23 FSC for rice-soybean based extrudates. At these combinations, optimum hydration properties were $97.10 \%$ DI, 6.11 WAI and $8.42 \mathrm{WSI}$, while proximate composition of $1.02 \%$ moisture content, $3.62 \%$ lipid, $26.26 \%$ protein, $0.48 \%$ ash content, $2.14 \%$ fibre, $70.13 \%$ and $412.14 \mathrm{kcal}$ of energy (Table 6) were the optimum value attained.

\section{Conclusions}

Extrusion cooking of varying formulations of composite flour of broken rice and soybean was performed for the production of extruded foods having good hydration characteristics and proximate composition using designed experiment and optimized by RSM. CCRD was used to evaluate and optimize the effects of barrel temperature, feed moisture content and feed soybean composition on the hydration and proximate composition. The results shows that the process variables significantly affect the hydration behavior and proximate composition of the rice-soybean extruded foods, while the high coefficient of determination of regression models fitted from the experimental data and the non-significant lack-of-fit indicated that the models could be used to satisfactorily predict the hydration and proximate composition during application.

The optimized hydration properties were 97\% dispersion index, $6.11 \mathrm{WAI}$ and 8.42 WSI, while proximate composition is of $1.02 \%$ moisture content, $3.62 \%$

Table 6. Constraints and goals applied to derive optimum conditions of processing parameters and responses for rice-soybean based formulations.

\begin{tabular}{|c|c|c|c|c|c|}
\hline Variables & Goal & $\begin{array}{c}\text { Upper } \\
\text { limit }\end{array}$ & $\begin{array}{c}\text { Lower } \\
\text { limit }\end{array}$ & Importance & $\begin{array}{l}\text { Optimum } \\
\text { level }\end{array}$ \\
\hline \multicolumn{6}{|c|}{ Independent variables } \\
\hline Moisture content (\% w.b) & In range & 8 & 24 & 3 & 20.00 \\
\hline Blend ration (\% legume) & In range & 15 & 25 & 3 & 23.00 \\
\hline Barrel Temperature $\left({ }^{\circ} \mathrm{C}\right)$ & In range & 100 & 140 & 3 & 130.00 \\
\hline \multicolumn{6}{|c|}{ Response variables } \\
\hline \multicolumn{6}{|c|}{ Functional characteristics } \\
\hline Dispersibility (DSPLTY) & Maximize & 96.99 & 98.16 & 5 & 97.10 \\
\hline Water absorption capacity (WAI) & Maximize & 6.13 & 7.28 & 5 & 6.11 \\
\hline Water solubility index (WSI) & Maximize & 8.31 & 8.93 & 5 & 8.42 \\
\hline \multicolumn{6}{|c|}{ Proximate composition } \\
\hline Moisture content (\%) & Minimize & 0.08 & 1.31 & 3 & 1.02 \\
\hline Lipid content $(\%)$ & Minimize & 3.20 & 4.36 & 3 & 3.62 \\
\hline Protein (\%) & Maximize & 21.93 & 28.30 & 5 & 26.26 \\
\hline Ash content (\%) & Minimize & 0.35 & 0.62 & 3 & 0.48 \\
\hline Fibre (\%) & Maximize & 0.77 & 3.22 & 5 & 2.14 \\
\hline Carbohydrate (\%) & Minimize & 66.30 & 73.00 & 3 & 70.13 \\
\hline Calorie value (kcal/100g) & Maximize & 403.97 & 416.08 & 3 & 412.14 \\
\hline
\end{tabular}


lipid, $26.26 \%$ protein, $0.48 \%$ ash content, $2.14 \%$ fibre, $70.13 \%$ carbohydrate and $412.14 \mathrm{kcal} / 100 \mathrm{~g}$ calorie value (Table 6). Therefore, the models can predict the extrusion condition in its natural state. Combining response surface methodology and extrusion cooking at the optimum process conditions not only improved the quality of rice-legume based food products but also simplified the experiment process. In order to develop extruded foods having functional health benefits and ensure the steady development of the cereal industry in sub Saharan Africa (SSA), appropriate processing and system analysis and development of extrusion cooking using common raw materials will provide scientific theoretical basis.

\section{Acknowledgements}

Financial and technical supports by Africa Rice Centre (AfricaRice) and Global Affairs Canada (GAC) under the Project "Enhancing food security in Africa through the improvement of rice post-harvest handling, marketing and the development of new rice-based products" (A034968) is highly acknowledged.

\section{References}

[1] Juliano, B.O. (2016) Rice: Overview. In: Wrigley, C., Corke, H., Seetharaman, K. and Faubion, J., Eds., Encyclopedia of Food Grains, Vol. 1, Academic Press, Oxford, 125-129. http://www.elsevier.com/locate/permissionusematerial https://doi.org/10.1016/B978-0-12-394437-5.00015-2

[2] USAID (2009) Nigerian Rice Value Chain Analysis. Draft Report, United Stated Agency for International Development, Abuja.

[3] Iwe, M.O., Van Zauilichaem, D.J., Ngoody, P.O. and Ariahu, C.C. (2001) Residence Time Distribution in a Single Screw Extruder Processing Soy Sweet Potato Mixtures. Food Science and Technology, 34, 478-483. https://doi.org/10.1006/fstl.2001.0785

[4] Iwe, M.O. (2003) The Science and Technology of Soybean. Rejoint Communication Services Ltd., Enugu.

[5] Filli, K.B., Nkama, I., Abubakar, U.M. and Jideani, V.A. (2010) Influence of Extrusion Variables on Some Functional Properties of Extruded Millet-Soybean for the Manufacture of "Fura": A Nigerian Traditional Food. African Journal of Food Science, 4, 342-352. http://www.academicjournals.org/ajfs

[6] Polhill R.M., Raven P.H. and Stirto, C.H. (1981) Evolution and Systematics of the Leguminosae. In: Polhill, R.M. and Raven, P.H., Eds., Advances in Legume Systematics, Part I, Royal Botanic Garden, Kew, 1-26.

[7] Garcia, M.C., Marina, M.L., Laborda, F. and Torre, M. (1998) Chemical Characterization of Commercial Soybean Products. Food Chemistry, 62, 325-331. https://doi.org/10.1016/S0308-8146(97)00231-8

[8] Graham, P.H. and Vance, C.P. (2003) Legumes: Importance and Constraints to Greater Uses. Plant Physiology, 131, 872-877. https://doi.org/10.1104/pp.017004

[9] Kenedy, A.R. (1995) The Evidence for Soybean Products as Cancer Preventive Agents. Journal of Nutrition, 125, S751-S756.

[10] Molteni, A., Brizio-Molteni, L. and Persky, V. (1995) In Vitro Hormonal Effects of Soybean Isoflavones. Journal of Nutrition, 125, S751-S743. 
[11] Iyer, V., Salunkhe, D.K., Sathe, S.K. and Rockland, L.B. (1980) Quick Cooking Beans (Phaseolus vulgaris L.). II: Phyates, Oligosaccharides and Antienzymes. Plant Foods for Human Nutrition, 30, 45-52. https://doi.org/10.1007/BF01112103

[12] Harper, J.M. and Jansen, G.R. (1985) Production of Nutritious Pre-Cooked Foods in Developing Countries by Low-Cost Extrusion Technology. Food Review International, 1, 27-97. https://doi.org/10.1080/87559128509540766

[13] Ryu, G.H., Neumann, P.E. and Walker, C.E. (1993) Effects of Some Baking Ingredients on Physical and Structural Properties of Wheat Flour Extrudates. Cereal Chemistry, 70, 291-297.

[14] Abd El-Hady, E.A., Mostafa, G.A., El-Samahy, S.K. and El-Saies, I.A. (1998) Production of High Fiber Corn Extrudates. Journal of Agricultural Science, 23, 1231 1245.

[15] Ding, Q.-B., Ainsworth, P., Tucker, G. and Marson, H. (2005) The Effect of Extrusion Conditions on the Physicochemical Properties and Sensory Characteristics of Rice-Based Expanded Snacks. Journal of Food Engineering, 66, 283-289. https://doi.org/10.1016/j.jfoodeng.2004.03.019

[16] Anderson, R.A., Conway, H., Pfeifer, V. and Griffin, L. (1969) Gelatinization of Corn Grits by Roll and Extrusion Cooking. Cereal Science Today, 14, 4-12.

[17] Moore, D., Sanei, E., Vanhecke, Z. and Bouvier, J.M. (1990) Effect of Ingredients on Physical/ Structural Properties of Extrudate. Journal of Food Science, 55, 1383-1387. https://doi.org/10.1111/j.1365-2621.1990.tb03942.x

[18] Akdogan, H. (1999) Pressure, Torque and Energy Responses of a Twin Screw Extruder at High Moisture Contents. Food Research International, 29, 423-429. https://doi.org/10.1016/S0963-9969(96)00036-1

[19] Bryant, R.J., Kadan, R.S., Champagne, E.J., Veinyard, B.T. and Boykin, B.B. (2001) Functional and Digestive Characteristics of Extruded Rice Flour. Cereal Chemistry, 78, 131-137. https://doi.org/10.1094/CCHEM.2001.78.2.131

[20] Danbaba, N., Nkama, I., Badau, M.H., Ukwungwu, M.N., Maji, A.T., Abo, M.E., Hauwawu, H., Fati, K.I. and Oko, A.O. (2014) Optimization of Rice Parboiling Process for Optimum Head Rice Yield: A Response Surface Methodology (RSM) Approach. International Journal of Agriculture and Forestry, 4, 154-165. https://doi.org/10.5923/j.ijaf.20140403.02

[21] Danbaba, N., Nkama, I. and Badau, M.H. (2015) Application of Response Surface Methodology (RSM) and Central Composite Design (CCD) to Optimize Minerals Composition of Rice-Cowpea Composite Blends during Extrusion Cooking. International Journal of Food Science and Nutrition Engineering, 5, 40-52. https://doi.org/10.5923/j.food.20150501.06

[22] Danbaba, N., Nkama, I. and Badau, M.H. (2016) Application of Response Surface Methodology for the Production and Optimization of Extruded Instant Porridge from Broken Rice Fractions Blended Cowpea. International Journal of Nutrition and Food Science, 5, 105-116. https://doi.org/10.11648/j.ijnfs.20160502.13

[23] Ganjyal, G., Hanna, M.A., Supprung, P., Noomhorm, A. and Jones, D. (2006) Modeling Selected Properties of Extruded Rice Flour and Rice Starch by Neural Networks and Statistics. Cereal Chemistry, 83, 223-227. https://doi.org/10.1094/CC-83-0223

[24] Ascheri, J.L.R. (2010) Curso de Processo de Extrusão de Alimentos: Aspectos T ecnológicospara o Desen v olvimento e Produção de Alimentospara Consumo Humano e Animal. 1-88.

[25] Likimani, T.A., Sofos, J.N., Maga J.A. and Harper, J.M. (1991) Extrusion Cooking of Corn/Soybean Mix Is Presence of Thermo-Stable $\alpha$-Amylase. Journal of Food Science, 
56, 99-105. https://doi.org/10.1111/j.1365-2621.1991.tb07985.x

[26] Filli, K.B., Nkama, I., Jideani, V.A. and Abubakar, U.M. (2011) Application of Response Surface Methodology for the Study of Composition of Extruded MilletCowpea Mixtures for the Manufacture of Fura: A Nigerian Food. African Journal of Food Science, 5, 884-896. https://doi.org/10.5897/AJFS11.169

[27] Anderson, R.A., Conway, H.F., Pfeifer, V.F. and Griffin, L.E.J. (1969) Roll and Extrusion Cooking of Grain Sorghum Grits. Cereal Science Today, 14, 372-375.

[28] Jin, Z., Hsieh, F. and Huff, H.E. (1995) Effect of Soy Fibre, Salt, Sugar and Screw Speed on Physical Properties and Microstructure of Corn Meal Extrudes. Journal of Cereal Science, 22, 185-194. https://doi.org/10.1016/0733-5210(95)90049-7

[29] Onwulata, C.I., Konstance, R.P., Smith, P.W. and Holsinger, V.H. (1998) Physical Properties of Extruded Products as Affected by Cheese Whey. Journal of Food Science, 63, 1-5. https://doi.org/10.1111/j.1365-2621.1998.tb17906.x

[30] AOAC (1984) Official Methods of Analysis. 14th Edition, Association of Official Analytical Chemists, Arlington.

[31] Box, G.E.P. and Hunter, J.S. (1957) Multifactor Experimental Designs for Exploring Response Surface. Annal of Mathematics and Statistics, 28, 195-241. https://doi.org/10.1214/aoms/1177707047

[32] Montgomery, D.C. (1997) Response Surface Methods and Other Approaches to Process Optimization. In: Montgomery, D.C., Ed., Design and Analysis of Experiment, John Wiley and Sons, New York, 427-510.

[33] Almeida-Dominguez, H.D., Gomez, M.H., Serna-Saldivar, S.O., Waniska, R.D., Rooney, L.W. and Lusas, W. (1993) Extrusion Cooking of Peal Millet for Production of Millet-Cowpea Weaning Foods. Cereal Chemistry, 70, 214-219.

[34] Kone, T. and Launay, B. (1987) Properties viscoelastiques at cinetique de retrogradation des empoisdamidon de mais extrude. Colloque de P INRA, 41, 153.

[35] Jackson, D.S., Waniska, R.D. and Rooney, L.W. (1998) Differential Water Solubility of Corn and Sorghum Starches and Their Characteristics by High Performance Size Extlusion Chromatography. Cereal Chemistry, 66, 228.

[36] Conway, H.F. (1971) Extrusion Cooking of Cereals and Soybeans. Part I. Food Product Development, 5, 27.

[37] Artz, W.E., Warren, C. and Villota, R. (1990) Twin-Screw Extrusion Modification of a Corn Fibre and Corn Starch Extruded Blend. Journal of Food Science, 55, 746750. https://doi.org/10.1111/j.1365-2621.1990.tb05220.x

[38] Badrie, N. and Mellowes, W.A. (1991) Effect of Extrusion Variables on Cassava Extrudates. Journal of Food Science, 56, 1334-1337. https://doi.org/10.1111/j.1365-2621.1991.tb04766.x

[39] Koocheki, A., Taherian, A.R., Razavi, S.M.A. and Bostan, A. (2009) Response Surface Methodology for Optimization of Extraction Yield, Viscosity, and Hue and Emulsion Stability of Mucilage Extracted from Lepidium perfoliatum Seeds. Food Hydrocolloids, 23, 2369-2379. https://doi.org/10.1016/j.foodhyd.2009.06.014

[40] Chauhan, B. and Gupta, R. (2004) Application of Statistical Experimental Design for Optimization of Alkaline Protease Production from Bacillus sp RGR-14. Process Biochemistry, 39, 12-45. https://doi.org/10.1016/j.procbio.2003.11.002

[41] Myers, R.H. and Montgomery, D.C. (2002) Response Surface Methodology: Product and Process Optimization Using Designed Experiments. 2nd Edition, John Wiley \& Sons, New York.

[42] Milán-Carrillo, J., Montoya-Rodríguez, A., Gutiérrez-Dorado, R., Perales-Sánchez, X. and Reyes-Moreno, C. (2012) Optimization of Extrusion Process for Producing 
High Antioxidant Instant Amaranth (Amaranthus hypochondriacus L.) Flour Using Response Surface Methodology. Applied Mathematics, 3, 1516-1525. https://doi.org/10.4236/am.2012.330211

[43] Wu, H., Wang O., Ma, T. and Ran, J. (2009) Comparative Studies on the Functional Properties of Various Proteins Concentrate Preparations of Peanut Protein. Food Research International, 42, 345-348. https://doi.org/10.1016/j.foodres.2008.12.006

[44] Charunuch, C., Tangkankul, P., Limsagoun, N. and Sonted, V. (2008) Effect of Extrusion Conditions on the Physical and Functional Properties of Instant Cereal Beverage Powders Admixed with Mulberry (Morusalba L.) Leaves. Food Science and Technology Research, 14, 421-430. https://doi.org/10.3136/fstr.14.421

[45] Camire, M.E., Camire, A. and Krumhar, K. (1990) Chemical and Nutritional Changes in Foods during Extrusion. Critical Review in Food Science and Nutrition, 29, 35 36. https://doi.org/10.1080/10408399009527513

[46] Marzec, A. and Lewiski, P.P. (2003) Anti-Plasticization of Cereal-Based Products by Water. Part I: Extruded Flat Bread. Journal of Food Engineering, 73, 1-8. https://doi.org/10.1016/j.jfoodeng.2004.12.002

[47] Mesquita, C.B., Leonel, M. and Mischan, M.N. (2013) Effect of Processing on Physical Properties of Extruded Snacks with Blends of Sour Cassava Starch and Flaxed Flour. Food Science and Technology, Campinas, 33, 404-410. https://doi.org/10.1590/S0101-20612013005000073

[48] Anuar, N., Adnan, A.F.M., Saat, N., Aziz, N. and Taha, R.M. (2013) Optimization of Extraction Parameters by Using Response Surface Methodology, Purification, and Identification of Anthocyanin Pigments in Melastoma malabathricum Fruit. The Scientific World Journal, 2013, Article ID: 810547. https://doi.org/10.1155/2013/810547

[49] Gupta, K., Mansi, V., Payal, J. and Monika, J. (2014) Process Optimization for Producing Cowpea Added Instant Kheer Mix Using Response Surface Methodology. Journal of Nutrition Health and Food Engineering, 1, 00030. https://doi.org/10.15406/jnhfe.2014.00030

\section{Abbreviations and Acronyms}

RSM $=$ Response Surface Design

CCRD = Central Composite Rotatable Design

$\mathrm{WAI}=$ Water Absorption Index

WSI $=$ Water Solubility Index

$\mathrm{DI}=$ Dispersion Index

SSA $=$ Sub Saharan Africa

AfricaRice $=$ Africa Rice Centre

$\mathrm{BRT}=$ Barrel Temperature

FMC $=$ Feed Moisture Content

FSC $=$ Feed Soybean Composition

NCRI = National Cereals Research Institute, Badeggi 
Submit or recommend next manuscript to OALib Journal and we will provide best service for you:

- Publication frequency: Monthly

- 9 subject areas of science, technology and medicine

- Fair and rigorous peer-review system

- Fast publication process

- Article promotion in various social networking sites (LinkedIn, Facebook, Twitter, etc.)

- Maximum dissemination of your research work

Submit Your Paper Online: Click Here to Submit

Or Contact service@oalib.com 